\title{
Determination of Selected Air Quality Parameters in Zaria and its Environs, Kaduna State, Nigeria
}

\author{
*NIMYEL, SH; NAMADI, MM \\ Department of Chemistry, Nigerian Defence Academy, Kaduna, Nigeria \\ "Corresponding Author Email: nimyela@gmail.com; Tel: +23408032918556
}

\begin{abstract}
The study determined some air quality parameters in Zaria and environs by monitoring the level of carbon monoxide, Sulphur (iv) oxide, Nitrogen (iv) oxide, and Hydrocarbon at five locations within the study area for eight weeks. The concentration of the gases was measured in part per million (ppm) using automatic hand held CrowconGasman Detection Instrument (model number EExias IIC T3/T4 and EExia IIC T3/T4 with certificate number Ex 93Y 2078 X and Ex 93C 2069 X respectively) manufactured by Crowcon Detection Instruments Ltd England that employs a catalytic beard sensor for methane gas and electrochemical sensors for the other gas measurements. The average concentrations of the gaseous emission were ranged: $\mathrm{CO}(2.78-33.48 \mathrm{ppm})$ which was recorded to be above the National Ambient Air Quality Standard (NAAQS) threshold range of $10-20 \mathrm{ppm}, \mathrm{NO}_{2}(0.006-0.052 \mathrm{ppm})$ was found to be within the NAAQS limit of $0.04-0.06 \mathrm{ppm}, \mathrm{SO}_{2}(0.003-0.037 \mathrm{ppm})$ was within the NAAQS limit of $0.01-0.1 \mathrm{ppm}$ and $\mathrm{HC}(0.005-0.038 \mathrm{ppm})$ which was found to be lower than the NAAQS limit of $0.05 \mathrm{ppm}$. The results indicate that the concentration of gaseous pollutants in the study area do not pose any major threat to the environment and humans.
\end{abstract}

DOI: $\underline{\text { https://dx.doi.org/10.4314/jasem.v23i8.14 }}$

Copyright: Copyright (C) 2019 Nimyel and Namadi. This is an open access article distributed under the Creative Commons Attribution License (CCL), which permits unrestricted use, distribution, and reproduction in any medium, provided the original work is properly cited.

Dates: Received: 24 June 2019; Revised: 29 July 2019; Accepted 21 August 2019

Keywords: Air, Pollution, Carbon monoxide, Sulphur (iv) oxide, Nitrogen (iv) oxide, and Hydrocarbon

The world's urban pollution has risen quicker over the last 5 centuries $(27 \%$ per year) than the complete population ( $1.8 \%$ per year) and is anticipated to increase to as much as 5 billion by 2030. (Parrish et al., 2011). The globe now has more urbanity than rural inhabitants with many evolving environmental implications for the first time in human history. (Bell et al., 2007; Crutzen 2004 and Parrish et al., 2011). A branch of this fast industrialization is the development of megacities (population $>10$ million) with a combined world population of nearly 300 million. Megacities are dense centers of the population, economic activity, and pollutant emissions; this implies that they are the areas where effective pollution control strategies could realize maximum benefit (Chan and Yao 2008; Molina and Molina 2004 and Parrish et al., 2011). The ongoing appraisal from the World Health Organization that 4.6 million individuals perish every year because of causes linked to air pollution raises worldwide worry, as epidemiologic investigations globally have given enough bits of knowledge into the relationship between pollution's due to gases and particulate matter, and the event of respiratory diseases, cardiovascular and cardiopulmonary mortality (Gupta et al., 2004; Koken et al., 2003). The level of air pollutants is increasing rapidly in many urban areas of megacities in the developing world. Due to the increased human activities, air pollution has become an intense topic of debate at all levels in Nigeria. (Ghose et al., 2004). There has been a fast rise in population growth, the number of motor vehicles, and the use of fuels with bad environmental performance, poorly maintained transport systems and inefficient environmental regulations resulting in increased air pollution in Nigeria's metropolitan regions (Olajire et al., 2011). Over the previous decades, Lagos State has experienced such issues of air pollution in all its severity, particularly as its metropolitan regions are linked with elevated industrial density and transport networks. These pollutants happen in many types, but can usually be considered as gaseous and particulate pollutants present in the atmosphere of the earth.

This study was conducted to determine the concentration of some gaseous pollutants at some selected location in Zaria metropolis, Kaduna state, Nigeria. The research aimed at assessing the level of air pollution in the selected areas in comparison with maximum allowable limits recommended by the national ambient air quality standard (NAAQS).

\section{MATERIALS AND METHOD}

Sampling Area: Zaria lies on latitude $11^{\circ} 10^{\prime} \mathrm{N}$ and longitude $7^{\circ} 35^{\prime} \mathrm{E}$ (Africa Atlas, 2002). It is located in the central area of what used to be called the Northern Region of Nigeria. The average annual rainfall in the region is between $924.3-$ and $1543.6 \mathrm{~mm}$. Annual temperature varies between $29^{\circ} \mathrm{C}-38.6^{\circ} \mathrm{C}$ (Africa Atlas, 2002). Zaria is a local government in Kaduna State.

The regions chosen for this inquiry are high-traffic and company areas. These areas are busy within the hours 
of $6.30-8.30$ am when offices and commercial activities commence and $4.00-7.30 \mathrm{pm}$ in the evening at the close of work and market activities.

Four sampling locations were selected and considered for this analysis. The Sites include; Kwangila, which is characterized by a minipark for trucks, petroleum dispensing station and runoff from the gutter; Tudun Wada roundabout, which houses a mini-park for vehicles and motorcycles, with shops surrounding the site and presence of refuse dump site; Chindict barracks junction which has a T-junction and a minipark for motorcycles and tricycles; and Aminu road Sabon-gari which has a mini-park for motorcycles and tricycles and also has boutiques and shops with regular use of generators and other gasoline-powered equipment. The sale of building materials is also noticed around the site as well as gutter presence. A last location known as Polo field was selected to serve as control as all the activities associated with the other locations are absent here.

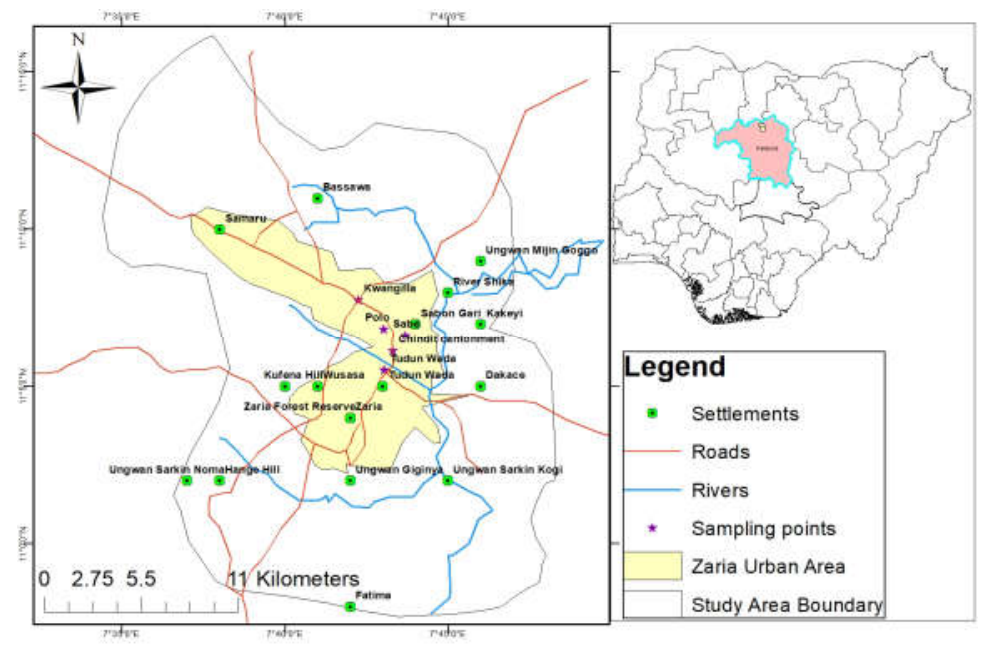

Fig 1: Map of Zaria showing the sampling locations

Determination of Gaseous Pollutants Concentration in Air: The levels of carbon (II) oxide (CO), sulphur (IV) oxide $\left(\mathrm{SO}_{2}\right)$, nitrogen (IV) oxide $\left(\mathrm{NO}_{2}\right)$ and hydrocarbons were detected at properly defined position of the selected locations. The ambient temperature around the location was measured and the co-ordinate of the sample point within the period of monitoring was recorded using Global Positioning System. The concentration of these gases were measured in part per million (ppm) using an automatic hand held Crowcon-Gasman Detection Instrument (model number EExias IIC T3/T4 and EExia IIC T3/T4 with certificate number Ex 93Y $2078 \mathrm{X}$ and Ex 93C 2069 X respectively) manufactured by Crowcon Detection Instruments Ltd England that employs a catalytic beard sensor for methane gas and electrochemical sensors for the other gas measurements. During the gas measurements the hand held equipment was held at about 1.5 meter above the ground level and the readings were recorded within ten seconds. All analyses were calibrated for zero and span before and after reading. Two sets of readings were recorded morning and evening in each month for the period of eight weeks.

\section{RESULTS AND DISCUSSION}

Mean Concentration of Air Pollutants: The concentrations of gaseous pollutant [Carbon monoxide, $(\mathrm{CO})$, nitrogen dioxide, $\left(\mathrm{NO}_{2}\right)$, Sulphur dioxide $\left(\mathrm{SO}_{2}\right)$ and hydrocarbon, $\left.(\mathrm{HC})\right]$ from vehicular emission and other anthropogenic activities are presented in figures 2-5. While table 1 shows the air quality guideline for the priority pollutants as provided by National ambient air quality standards (NAAQS).

Table 1. Air Quality Guideline for the Priority Pollutants \begin{tabular}{ll}
\hline POLLUTANTS & NAAQS \\
\hline $\mathbf{C O}$ & $10-20 \mathrm{ppm}$ \\
$\mathbf{S O}_{2}$ & $0.01-0.1 \mathrm{ppm}$ \\
$\mathbf{H C}$ & $0.05 \mathrm{ppm}$ \\
$\mathrm{NO}_{2}$ & $0.04-0.6 \mathrm{ppm}$ \\
\hline
\end{tabular}

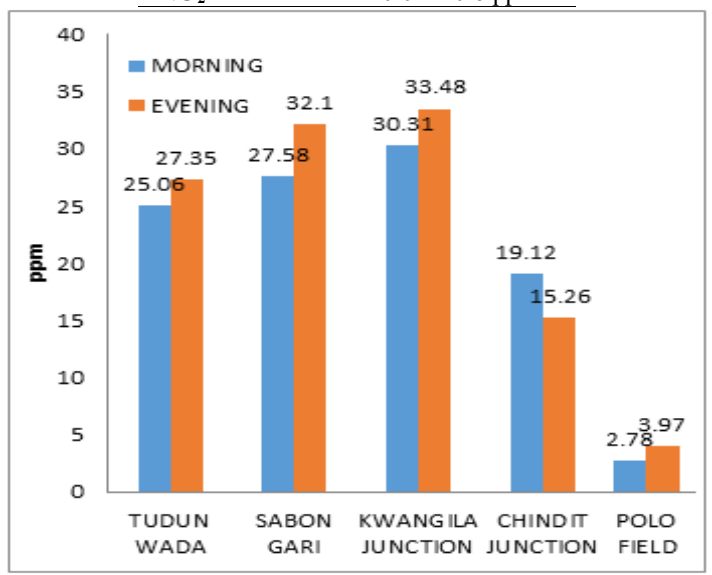

Fig 2: Variations in the levels of CO at sampling sites in Zaria Metropolis 
As presented in Figure 2. From these results, the concentrations of $\mathrm{CO}$ during evening peak were higher than those obtained during their respective morning periods at all the experimental sites except Chindit Barracks which had higher concentration during the morning peak period than evening, this higher concentration during the evening peak period could be as a result of residual accumulation from morning and afternoon. The concentrations of $\mathrm{CO}$ at the experimental sites were higher than the NAAQS threshold range of $10-20 \mathrm{ppm}$ except for Chindit Junction and Polo field (used as the control site) which were found to be lower or within the ranges in the morning and evening hours. Although the results were found to be higher than the $1.25-4.00 \mathrm{ppm}$ range reported for Tse-Kucha community of Benue State of Nigeria by Abdulkarim and Chiroma., (2007). However, the values were lower than a range of 233.0 to $317.0 \mathrm{ppm}$ reported in three cities of Nigeria: Lagos, Ado-Ekiti and Ibadan (Koku and Osuntogun, 2007). It is also lower than the range of 60 to $110 \mathrm{ppm}$ in Jos metropolis as reported by Ola et al., (2013). The concentrations of $\mathrm{CO}$ at all the sites were found to be higher than Polo Field used as the control site where little or no vehicular activities were found. high $\mathrm{CO}$ concentration levels were found in Kwangila junction, Sabon Gari and Tudun Wada sampling sites could be attributed to other sources of pollution at these sampling locations apart from vehicular emission such as be burning of wood for cooking, burning of dump refuse and expired vehicle tires. Comparing the mean concentration values of $\mathrm{CO}$ across periods at the sampling locations, the highest value was recorded at Kwangila in the evening period due to traffic congestion, commercial congestion, and other activities. The site is located close to a motor park and a mini market congested with people who cause traffic congestion and slow movement of vehicle. It is also few meters away from refuse dump and serves as temporary bus stop for most intra-city buses, taxies, and motorcycles thereby experiencing flux of traffic, especially during evening hours. This indicated that Kwangila dwellers and trade hawkers were generally exposed to the higher levels of carbon monoxide which is also above the World Health Organization (WHO) permitted value of less than 9 ppm over 8-hour period. These results reveal that pollution and activities in Zaria LGA especially around Tudun wada, Sabon gari and Kwangila junction resulting to $\mathrm{CO}$ emission is slightly significant with potentially hazardous health consequences. Figure 3. Shows the concentrations of $\mathrm{NO}_{2}$ during morning peak traffic period were $0.031 \pm 0.009$, ppm, $0.031 \pm 0.009,0.006 \pm 0.004 \mathrm{ppm}$, $0.052 \pm 0.043 \mathrm{ppm}$ and $0.023 \pm 0.006$ at Tudun wada, Sabon gari, Polo field, Kwangila junction, and Chindit Barracks respectively. The concentrations for evening peak traffic period were $0.038 \pm 0.007 \mathrm{ppm}$, $0.035 \pm 0.009 \mathrm{ppm}, 0.010 \pm 0.004 \mathrm{ppm}, 0.028 \pm 0.007$ ppm and $0.023 \pm 0.004$ ppm at Tudun wada, Sabon gari,
Polo field, Kwangila junction, and Chindit Barracks respectively.

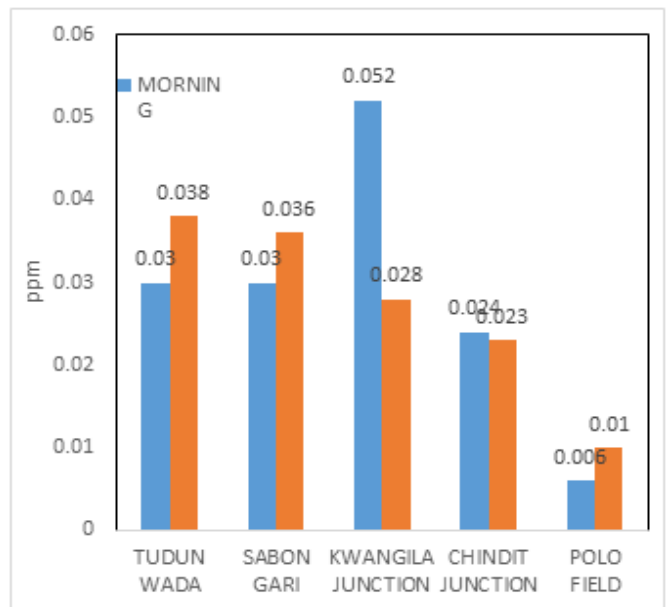

Fig 3: Variations in the levels of $\mathrm{NO}_{2}$ at sampling sites in Zaria Metropolis

The highest concentration of $0.052 \pm 0.043 \mathrm{ppm}$ for $\mathrm{NO}_{2}$ was found at Kwangila junction during the morning period. This could also be attributed to the higher number of heavy-duty vehicles at Kwangila junction which naturally will emit more $\mathrm{NO}_{2}$ than light vehicles (Tsai et al., 2006; Sawyer, 2010). These results showed that vehicular emission had contributed to higher values of $\mathrm{NO}_{2}$ concentration in the air at all the experimental sites when compared to the concentrations at the control where there were very few vehicles. The concentrations of $\mathrm{NO}_{2}$ as presented in Figure 4.2 were all within the standard limit range of $0.04-0.06$ ppm by NAAQS. the levels of $\mathrm{NO}_{2}$. when compared with available values reported in the literature, the mean of $\mathrm{NO}_{2}$ was found lower than 35 to $108 \mathrm{ppm}$ reported in Athens by Kalabokas et al., (1999), and 0.14 to $1.09 \mathrm{ppm}$ as reported for Kano metropolis, Nigeria (Okunola, et al., 2012). However, the values were found to be within the range 0.02 to $0.06 \mathrm{ppm}$ reported for Calabar metropolis, Nigeria by Okafor et al., (2009). It is quite lower than the standard value limit set by FEPA, 1991 for $\mathrm{NO}_{2}$ which is 0.06 ppm. $\mathrm{NO}_{2}$ presence is due to high traffic density and stationary fuel combustion process emissions from running of generators, trucks, and tanks (Etiuma and Ekpok., 2006) which are very common at the Kwangila sampling site due to erratic power supply, movement of goods and petroleum products. Nitrogen (IV) oxide is a greenhouse gas pollutant because of its role in forming brown haze and photochemical reaction with ozone and organic compounds to form photochemical smogs such as peroxy acetyl nitrate (PAN). As presented in Figure 4. The concentrations of $\mathrm{SO}_{2}$ during morning peak traffic period were 0.032 $\pm 0.008 \mathrm{ppm}, 0.034 \pm 0.009 \mathrm{ppm}, 0.003 \pm 0.008 \mathrm{ppm}$, $0.030 \pm 0.009$ and $0.019 \pm 0.003 \mathrm{ppm}$ at Tudun wada, Sabon gari, Polo field, Kwangila junction, and Chindit Barracks respectively. 


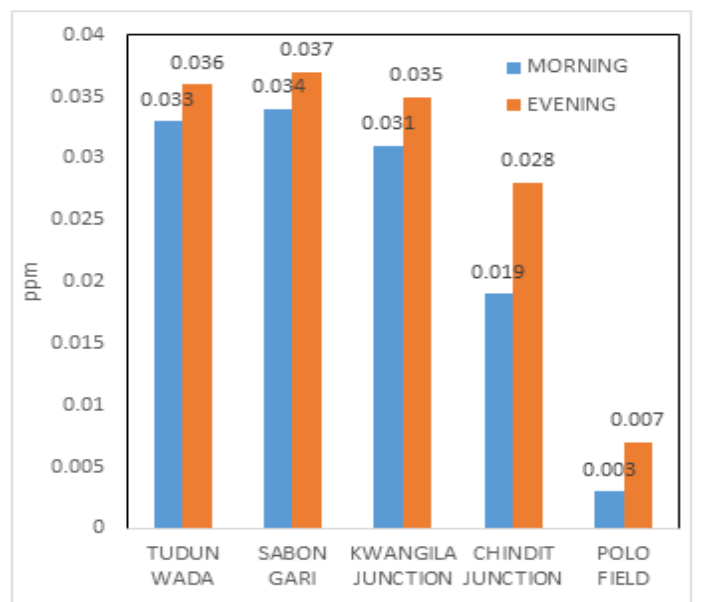

Fig 4: Variations in the levels of $\mathrm{SO}_{2}$ among sampling sites in Zaria Metropolis

The concentrations for evening peak traffic period were $0.035 \pm 0.007 \mathrm{ppm}, 0.037 \pm 0.008 \mathrm{ppm}, 0.007 \pm$ $0.004 \mathrm{ppm}, 0.035 \pm 0.007 \mathrm{ppm}$ and $0.028 \pm 0.006 \mathrm{ppm}$ at Tudun wada, Sabon gari, Polo field, Kwangila junction, and Chindit Barracks respectively. The concentrations of $\mathrm{SO}_{2}$ during evening peak traffic period were higher than the concentrations obtained during morning peak traffic $\mathrm{SO}_{2}$ concentrations during peak traffic periods at all experimental sites and were all within the $0.01-0.1 \mathrm{ppm}$ standard range limit by NAAQS. The average concentration ranges between $0.021-0.037 \mathrm{ppm}$ measured at experimental sites during the evening peak traffic periods is better compared to the $0.04-0.15 \mathrm{ppm}$ range reported by Abam and Unachukwu (2009) and since this range of $0.021-0.037 \mathrm{ppm}$ is within the NAAQS limit range of $0.01-0.1 \mathrm{ppm}$, it is safe to the environment. The mean concentration of Sulphur (IV) oxide across periods along sampling locations indicated that the highest level was observed in the evening period of sample collection at Tudun Wada, Sabon Gari, and Kwangila. When compared with other studies, the literature concentration of $\mathrm{SO}_{2}$ was found to be lower than range of 3.21 to $5.18 \mathrm{ppm}, 7.4$ to $15.5 \mathrm{ppm}$ and 16 to $64 \mathrm{ppm}$ reported by Ayodele and Abubakar (2008), Ettouney et al., (2010) and Kalabokas et al., (1999) respectively. In term of ambient air quality standard at all locations, the emission concentrations were also within average value for 24 hours' limit of $0.14 \mathrm{ppm}$ set by United State Environmental Protection Agency (USEPA, 2009). Sulphur (IV) oxide is recognized greenhouse gas pollutant because of its role in forming cold time smog (Hermann, 1991). $\mathrm{SO}_{2}$ is an acidic, irritant gas which in high concentrations can cause constriction of the airways such as nose, throat, and lung (Wholf et al., 1975; Ayodele and Abubakar, 2010). From the above results, the concentrations of $\mathrm{SO}_{2}$ in the air of Zaria LGA at all experimental sites were within safe limit.

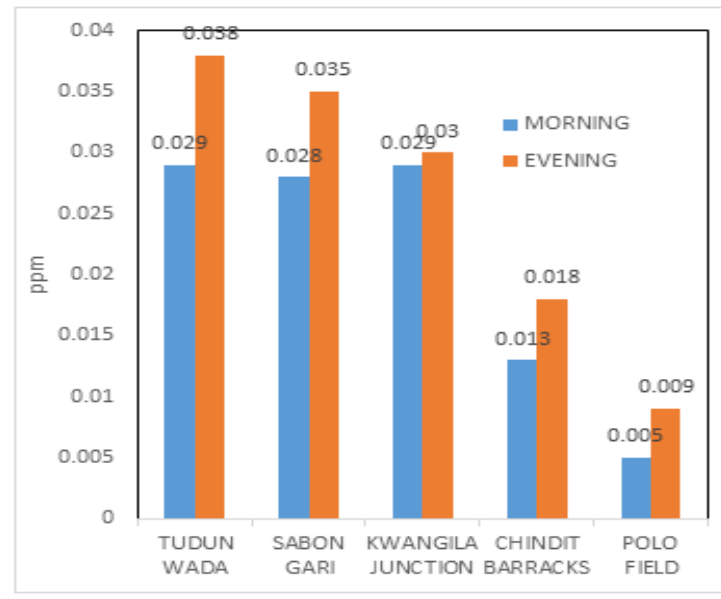

Fig 5: Variations in the levels of HCs among sampling sites in Zaria Metropolis

As presented in Figure 4.4. The morning peak traffic levels of HCs were $0.029 \pm 0.009 \mathrm{ppm}, 0.027 \pm 0.006$ ppm, $0.005 \pm 0.004 \mathrm{ppm}, 0.029 \pm 0.010$ and $0.012 \pm$ $0.003 \mathrm{ppm}$ at Tudun wada, Sabon gari, Polo field, Kwangila junction, and Chindit Barracks respectively. The levels for the traffic peak at evening were $0.037 \pm$ $0.008 \mathrm{ppm}, 0.035 \pm 0.008 \mathrm{ppm}, 0.009 \pm 0.006 \mathrm{ppm}$, $0.030 \pm 0.006 \mathrm{ppm}$ and $0.018 \pm 0.005 \mathrm{ppm}$ for Tudun wada, Sabon gari, Polo field, Kwangila junction and Chindit Barracks respectively. During the evening peak traffic levels of HCs were greater than those acquired during their respective morning peak traffic period as in the event of SO2. This could be attributed to the high vehicular volume traffic jam, increased burning of tyres and other anthropogenic activities. The concentrations of $\mathrm{HCs}$ at all experimental locations during morning and evening peak traffic were less than the NAAQS limit of $0.05 \mathrm{ppm}$. When compared with others studies, the literature concentration of $\mathrm{HC}$ as recorded by Okonkwo et al., (2012) who carried out a study in Port Harcout city of River State, Nigeria, the mean concentration was found to be lower than $0.6 \mathrm{ppm}$ during the morning period and 0.53 to 0.58 in the evening.

Correlation between Air Pollutants in the Morning and Evening: Correlation between Air Pollutants in the Morning

Table 2. Correlation of Air Pollutant in the Morning

\begin{tabular}{lllll}
\hline & $\mathrm{CO}$ & $\mathrm{NO}_{2}$ & $\mathrm{SO}_{2}$ & $\mathrm{HC}$ \\
\hline $\mathrm{CO}$ & 1 & & & \\
$\mathrm{NO}_{2}$ & $.835^{* *}$ & 1 & & \\
$\mathrm{SO}_{2}$ & $.798^{* *}$ & $.757^{*}$ & 1 & \\
$\mathrm{HC}$ & $.909^{* *}$ & $.889^{* *}$ & .577 & 1 \\
\hline
\end{tabular}

**Correlation is significant at the 0.01 level (2-tailed).

*Correlation is significant at the 0.05 level (2-tailed).

Table 2. shows that the correlation coefficient statistical analysis conducted on the air pollutants at 95 $\%$ and $99 \%$ confidence level indicates a significant positive correlation relationship between $\mathrm{NO}_{2}$ and $\mathrm{CO}$ $(\mathrm{r}=0.835), \mathrm{SO}_{2}$ and $\mathrm{CO}(\mathrm{r}=0.789), \mathrm{SO}_{2}$ and $\mathrm{NO}_{2}(\mathrm{r}=$ 
0.757), $\mathrm{HC}$ and $\mathrm{CO}(\mathrm{r}=0.909), \mathrm{HC}$ and $\mathrm{NO}_{2}(\mathrm{r}=$ $0.889)$ and $\mathrm{HC}$ and $\mathrm{SO}_{2}(\mathrm{r}=0.577)$. This indicates that the sources of the air pollutants in the morning hours is as a result of similar factors i.e vehicular emission, Garbage dumps, and other similar anthropogenic activities

Correlation between Air Pollutants in the Evening

Table 3. Correlation of Air Pollutant in the Evening

\begin{tabular}{|c|c|c|c|c|}
\hline & $\mathrm{CO}$ & $\mathrm{NO}_{2}$ & $\mathrm{SO}_{2}$ & $\mathrm{HC}$ \\
\hline $\mathrm{CO}$ & 1 & & & \\
\hline $\mathrm{NO}_{2}$ & $.787^{* * *}$ & 1 & & \\
\hline $\mathrm{SO}_{2}$ & $.940^{* * *}$ & $.906^{* *}$ & 1 & \\
\hline $\mathrm{HC}$ & $.876^{* * *}$ & $.974^{* *}$ & $.929^{* *}$ & 1 \\
\hline
\end{tabular}

In Table 3, the correlation coefficient statistical analysis conducted on the air pollutants at $95 \%$ confidence level indicates a significant positive correlation relationship in the evening between $\mathrm{NO}_{2}$ and $\mathrm{CO}(\mathrm{r}=0.787), \mathrm{SO}_{2}$ and $\mathrm{CO}(\mathrm{r}=0.940), \mathrm{SO}_{2}$ and $\mathrm{NO}_{2}(\mathrm{r}=0.906), \mathrm{HC}$ and $\mathrm{CO}(\mathrm{r}=0.876), \mathrm{HC}$ and $\mathrm{NO}_{2}$ $(\mathrm{r}=0.974)$ and $\mathrm{HC}$ and $\mathrm{SO} 2(\mathrm{r}=0.929)$. This relationship indicates the interdependence of these air pollutant pairs and could be said to be due to the presence of these air pollutants in similar source (i.e. vehicular emissions, garbage dumps, and other similar activities).

Conclusion: The results indicate that the concentration of gaseous pollutants do not pose any major threat to the environment and humans, however, it is imperative that continuous checks are done for the level of pollutants especially $\mathrm{CO}$ which was observed to be higher than the NAAQS threshold range in some sites. The study also shows positive significant correlation at $95 \%$ and $99 \%$ confidence level between the gaseous air pollutants.

Acknowledgment: The author acknowledge the financial support of the Nigerian Army and tertiary education trust fund (TETFUND) and Nigerian Defence academy for providing the plat form of this research.

\section{REFERENCES}

Abam, FI; Unachukwu, GO (2009). Vehicular Emission and Air Quality standards in Nigeria. Europe. J. Sci. Res. 34 (4) 550- 560

Abdulkarim, BI; Chiroma, TM (2007). Assessement of $\mathrm{CO}, \mathrm{CO} 2$ and suspended particulate matter emissions, Leonardo Elect. J. Pract. Technol. 6 (11): $109-116$

Ayodele, JT; Abubakar, F (2008). Indoor Hydrogen sulphide in Kano atmosphere, Kano, Nigeria. Trop. Environ.. Residences. 8
Ayodele, JT; Abubakar, F (2010). Sulphur dioxide as indoor pollutant in Kano Municipality KanoNigeria. Journal of environmental chemistry ecotoxicology, 2(1), 009-014.

Bell, ML; Goldberg, R; Hogrefe, C; Kinney, PL; Knowlton, K; Lynn, B; Patz, JA (2007). Climate change, ambient ozone, and health in 50 US cities. Climatic Change, 82(1-2), 61-76.

Chan, CK; Yao, X (2008). Air pollution in mega cities in China. Atmospheric environment, 42(1), 1-42

Crutzen, PJ (2004). New Directions: The growing urban heat and pollution" island" effect--impact on chemistry and climate. Atmospheric environment, 38, 3539-3540

Etiuma, A; Ekpok, E (2006). Reducing Greenhouse gas through Clean Development mechanism; Prospect and Challenges for Developing nation "The Preceding of a one-day seminar on Renewable energy; The key to sustainable energy Development in Nigeria. Organized by Community Research and Development Center CRDC.

Ettouney, RS; Zaki, JG; El-Rifiai, MA; Ettouney, HM (2010). An Assessment of the Air Pollution Data from Two Monitoring Station in Kuwait, Toxicology and Environmental Chemistry, 92(4): 655 - 668.

Ghose, MK; Paul, R; Banerjee, SK (2004). Assessment of the impacts of vehicular emissions on urban air quality and its management in Indian context: the case of Kolkata (Calcutta). Environmental Science \& Policy, 7(4), 345-351.

Gupta, AK; KararKakoli; Ayoob, S; John, K (2004). Spatio - temporal characteristics of gaseous and particulate pollutants in an urban region of Kolkata, India. Atmospheric research, 87, pp. 103-115.

Hermann (1991). Handbook of environmental health and safety principles and practices. Lewies publishers, Boca Raton, Florida 33431.

Kalabokas, PD; Viras, LG; Repapis, CC (1999). Analysis of the 11-year record (1987-1997) of air pollution measurements in Atthen, Greece, part 1: Primary pollution Global Nest: The International Journal, 1(3): 157 - 167.

Koken, PJ; Piver, WT; Ye, F; Elixhauser, A; Olsen, LM; Portier, CJ (2003). Temperature, air pollution, and Hospitalization for Cardiovascular Diseases among elderly people 
in Denver. Environmental health perspectives, 111(10), 1312.

Kokun, CA; Osuntogun, BA (2007). EnvironmentalImpacts of Road Transportation in SouthWestern States of Nigeria. Journal of Applied Sciences 7(16): 2536 - 2360.

Molina, MJ; Molina, LT (2004). Megacities and atmospheric pollution. J. Air. Waste. Manage. Assoc. 54(6), 644-680.

Okafor, PC; Ekpe, UI; Ibok, UJ; Ekpo, BO; Ebenso, EE; Obadimu, CO (2009). Atmospheric Corrosion of mild Steel in the Niger Delta Region of Nigeria. Part 1; characterization of the Calabar, Cross River State Environment. Global J. Environ. Sci. 8(1): 9 - 18.

Okonkwo, SI; Okpala, KO; Opara, MF (2012). Assessment of Automobile Induced Pollution in an Urban Area (A Case Study of Port Harcourt City, River State, Nigeria). International conference on Environmental, Biomedical, and Biotechnology. IPCBEE 41(2012). Press Singerpore.

Okunola, OJ; Uzairu, A; Gimba, CE; Ndukwe, GI (2012). Assessment of Gaseous pollutants along High Traffic roads in Kano, Nigeria. Inter. J. Environ. Sustain. 1(1): 1 - 5.
Ola, SA; Salami.SJ; Ihom, PA (2013). The Level of Toxic Gases $\mathrm{CO}, \mathrm{H}_{2} \mathrm{~S}, \mathrm{PM}$ to Index pollution in Jos metropolis, Nigeria. J. Atmos. Pollute. 1(1); $8-11$

Olajire, AA; Azeez, L; Oluyemi, EA (2011). Exposure to hazardous air pollutants along Oba Akran road, Lagos-Nigeria. Chemo. 84(8), 10441051.

Parrish, DD; Singh, HB; Molina, L; Madronich, S (2011). Air quality progress in North American megacities: A review. Atmos. Environ. 45 (39), 7015-7025.

Sawyer, RF (2010). Vehicle emissions: progress and challenges. J. Expo. Sci. Environ. Epidemiol. $20(6), 487$.

Tsai, WY; Chan, LY; Blake, DR; Chu, KW (2006). Vehicle fuel composition and atmospheric emission in south China: Hong Kong, Macau, Ghanzhou, and Zhuhai. Atmos. Chem. Physic. Discuss. 6: $3687-3707$

United State Environmental Protection Agency (USEPA) (2009). Waste and Climate Change, Global trend and strategies framework. Retrieved from http://www.unep.orjp/ietc /publications/wasteandclimatechange.pdf.

Wholf, RKM; Dolowich, M; Rossman, G.M; New house, MT (1975). Sulphur dioxide and tracheobronchial clearance in man. Arch Environ Health. 30: 521 - 527. 